\title{
Telogen Effluvium: Potential causes in Iraq
}

\author{
Alaa Abdulhassan Naifralaa-abd@utq.edu.iq \\ M.B.Ch.B, M.Sc. (Dermatol) , School of Medicine / Thi-Qar University
}

\begin{abstract}
:
Background: Telogen Effluvium (TE) among women is a challenging common problem for Dermatologists and data on its prevalence among Iraqi women is limited hair loss is a distressing problem for women because femininity and attractiveness is linked to women's hair.

Aim of study: To find out the main risk factors of Telogen Effluvium among women in Thi-Qar Province ( Iraq ). Some of these risk factors are investigated before in Iraq but not in Thi-Qar province such as TSH while others such as Vitamin D are barely investigated in Iraq.

Patients and methods: A descriptive cross sectional study carried out in Dermatology Outpatient Clinic of Al-Hussein Teaching Hospital, Nassiriah City ( Thi-Qar Province Center), Iraq through the period from $1_{\text {st }}$ of March, 2014 to the end of June, 2015 on random sample of 100 women with Telogen Effluvium and convenient sample of 100 healthy controls. Thyroid stimulating hormone, serum Ferritin and Vitamin $\mathrm{D}_{3}$ levels of both groups were measured.

Results: There was a significant association between positive family history of hair loss and women with Telogen Effluvium $(p<0.001)$. No significant difference in thyroid stimulating hormone level was observed between cases and controls $(p=0.6)$. There was a significantly lower serum Ferritin and Vitamin $\mathrm{D}_{3}$ levels among women with Telogen Effluvium ( $\mathrm{p}<0.05)$.

Conclusion: Low serum Ferritin and Vitamin D3 levels among women might play a major role in etiology of Telogen Effluvium.
\end{abstract}

Keywords: Hair loss, Telogen Effluvium, Thyroid Stimulating Hormone, Serum Ferritin, Vitamin $\mathrm{D}_{3}$.

\section{Introduction}

Hair loss among women is a challenging common problem for Dermatologists. Hair loss prevalence among Iraqi women is unknown while it affects more than $25 \%$ of women in developed countries $^{1}$. The most frequent causes of hair loss are Telogen Effluvium (TE) and female pattern hair loss (FPHL) ${ }^{2}$. TE (acute and chronic) is developed by shift of high number of Anagen hairs to 


\section{Email:utjmed@utq.edu.iq}

Telogen hairs on scalp ( the Anagen / Telogen Ratio ) changes from 90/10 to 70/30) and in general, the main risk factors of TE are major illness, stress, nutritional deficiencies and medications ${ }^{3}$.FPHL (familial disease) had an androgen and genetics basis in its etiology 4 .

Iron deficiency anemia is the most prevalent nutritional risk factor that faces the dermatologists in daily clinical practice ${ }^{5}$. A serum Ferritin level is used for hair loss assessment and iron supplement is used routinely for hair loss treatment. In spite of this, other authors failed to prove that the iron has an effect on hair loss ${ }^{6}$. Many observational studies have found the association between decreased Ferritin levels and hair loss ${ }^{7-10}$. The Ferritin is an acute-phase reactant and elevated as a result of many inflammatory diseases, therefore, a normal Creactive protein (CRP) is useful to exclude elevated Ferritin caused by acute-phase reactions ${ }^{11}$.

Vitamin D has a novel role in calcium regulation and bone metabolism and 1 , 25-dihydroxyvitamin D3 $\left[1,25(\mathrm{OH})_{2}\right.$ $\mathrm{D}_{3}$ ] affects other important physiological effects, as immunoregulation and protection against UV radiation, infectious agents, oxidative stress, and cancer ${ }^{12}$. Vitamin D activates hair follicle differentiation, without affecting proliferation. It was shown that the patients with hereditary vitamin D receptor (VDR) deficiency have a high probability of developingalopecia ${ }^{13}$.

Early onset type of FPHL among females has a stronger family history of male family members with significant male pattern baldness. Those women are more likely than those with late onset FPHL to have a history of hirsutism, adult acne that is persistent, or irregular periods and all potential signs of either androgen excess or androgen hypersensitivity. Late onsets FPHL among females had less androgen excess features and their blood androgen levels related to menopause with uncertain etiology of hair loss ${ }^{14}$.

Literatures on TE among Iraqi women are scarce although it's medical, aesthetic and social impact. Consequently, our study aimed to find out the main risk factors of TE among women in Thi-Qar Province (Iraq).

\section{Patients and Methods}

A descriptive cross sectional study carried out in Dermatology Outpatient Clinic of Al-Hussein Teaching Hospital, Nassiriah City ( Thi-Qar Province Center), Iraq through the period from $1^{\text {st }}$ of March, 2014 to end of June, 2015. The sample size of the study was calculated by the equation $\left(\text { Sample size }=\mathrm{Z}_{1-\alpha / 2}{ }^{2} \mathrm{P}(1-\mathrm{P}) / \mathrm{d}^{2}\right)^{15}$ with previous proportion extracted by a pilot study. The controls were selected with a case control ratio as $1: 1$. The study enrolled 15 to 50 year old women who were in generally good health, complained of self-perceived diffuse hair loss of at least one hundred hairs a day for at least six months. Women who were excluded were those with patchy hair loss, scarring hair loss, central scalp hair loss, frontal accentuation(female pattern hair loss), negative hair-pull test; a history of 


\section{Email:utjmed@utq.edu.iq}

using hair dye, perm or straightener within the last six months; women who were going on diet for the previous six months; women who had started taking drugs that affect hair cycles such as chemotherapy or hormonal therapy for birth control and infertility for the last six months; women with a pre-existing thyroid diseases or autoimmune diseases; women who were or had been pregnant or nursing within the previous one year; women currently taking iron or Vitamin D supplements(prior supplements is not an exclusion criterion). A sample of 100 women with TE was collected by systematic random sampling and a convenient sample of 100 healthy controls who presented to the same Dermatology Clinic for another complain such as wart, psoriasis, etc., and who were agreed to participate. Diagnosis of TE was done by researcher and based on the chief complain of self-perceived hair loss of at least one hundred hairs a day for at least six months in addition to the examination of scalp and performing a
Web Site: https://imed.utq.edu.iq

hair-pull test. Questionnaire designing was based on previous literatures ${ }^{1,2}$. The investigations (TSH, 1, 25(OH) 2 $\mathrm{D}_{3}$ and Ferritin) were done in laboratory of the hospital.

The study was approved by health authority in of Al-Hussein Teaching Hospital. All patients' data were entered using computerized statistical software; Statistical Package for Social Sciences (SPSS) version 21. Kolmogorov Smirnov analysis verified the normality of the data set. Descriptive statistics presented as (mean \pm standard deviation) and frequencies as percentages. Multiple contingency tables conducted and appropriate statistical tests performed, Chi-square used for categorical variables and Independent Samples t-test was used to compare between two means. Partial correlation test was used to assess the relationship between variables after controlling one variable. In all statistical analysis, level of significance ( $p$ value) set at $\leq 0.05$ and the result presented as tables and/or graps.

\section{Results}

A total of one hundred women having TE were included with mean age as $28.6 \pm 8.1$ years. No significant difference in age was observed between women with TE and controls $(\mathrm{p}=0.3) .63 \%$ of studied women with TE had a positive family history of the hair loss and $27 \%$ of healthy controls had a positive family history of hair loss. There was a significant association between positive family history of hair loss and women with TE $(\mathrm{p}<0.001)$. All these findings were shown in table 1 and figure 1. 
Table 1: Age and Family History for patients with TE and Healthy Controls.

\begin{tabular}{|c|c|c|c|}
\hline \multirow[t]{2}{*}{ Variable } & TE & No TE & \multirow[t]{2}{*}{$\mathbf{P}$} \\
\hline & No. $(\%)$ & No. $(\%)$ & \\
\hline \multicolumn{3}{|l|}{ Age } & \multirow{6}{*}{0.08} \\
\hline$<20$ years & $8(8.0)$ & $8(8.0)$ & \\
\hline 20-29 years & $53(53.0)$ & $37(37.0)$ & \\
\hline 30-39 years & $25(25.0)$ & $41(41.0)$ & \\
\hline$\geq 40$ years & $14(14.0)$ & $14(14.0)$ & \\
\hline Total & $100(100.0)$ & $100(100.0)$ & \\
\hline Mean+SD (years) & $28.6 \pm 8.1$ & $29.6 \pm 9.4$ & 0.3 \\
\hline \multicolumn{3}{|l|}{ Family history } & \multirow{4}{*}{$<0.001$} \\
\hline Positive & $63(63.0)$ & $27(27.0)$ & \\
\hline Negative & $37(37.0)$ & $73(73.0)$ & \\
\hline Total & $100(100.0)$ & $100(100.0)$ & \\
\hline
\end{tabular}

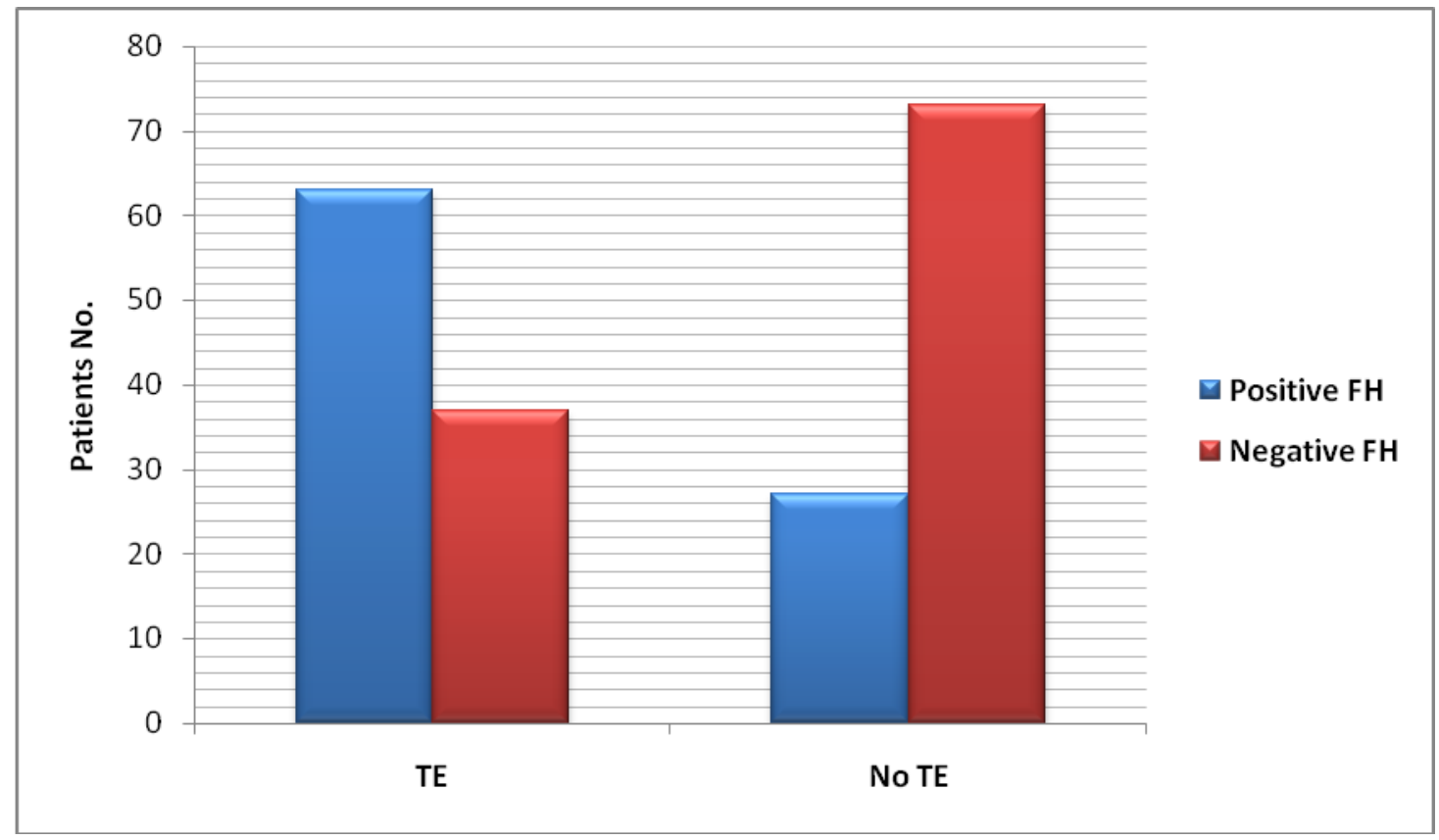

Figure 1: Family History (FH) of hair Loss Distribution according to Study Groups. 
No significant effect of TSH on hair loss in patients with TE was detected in present study $(\mathrm{p}=0.6)$. There was a statistically significant low Vitamin $\mathrm{D}_{3}$ level among women with TE $(p<0.001)$. A significant association was observed between low serum Ferritin and women with TE $(\mathrm{p}=0.01)$. All these findings were shown in table 2 and figure 2 .

Table 2: Distribution of Investigation Results according to Patients with TE and Healthy Controls.

\begin{tabular}{|l|c|c|c|}
\hline Investigations & TE & No TE & \multirow{2}{*}{ P } \\
\cline { 2 - 4 } & Mean \pm SD & Mean \pm SD & \\
\hline TSH $(\boldsymbol{\mu U} / \mathbf{m l})$ & $1.9 \pm 1.5$ & $2 \pm 1.1$ & 0.6 \\
\hline Vitamin $\mathbf{D}_{3}(\mathbf{p g} / \mathbf{m l})$ & $7.4 \pm 4.9$ & $18.2 \pm 12.4$ & $<0.001$ \\
\hline Serum Ferritin $(\mathbf{n g} / \mathbf{m l})$ & $46.1 \pm 37.5$ & $66.7 \pm 73.8$ & 0.01 \\
\hline
\end{tabular}

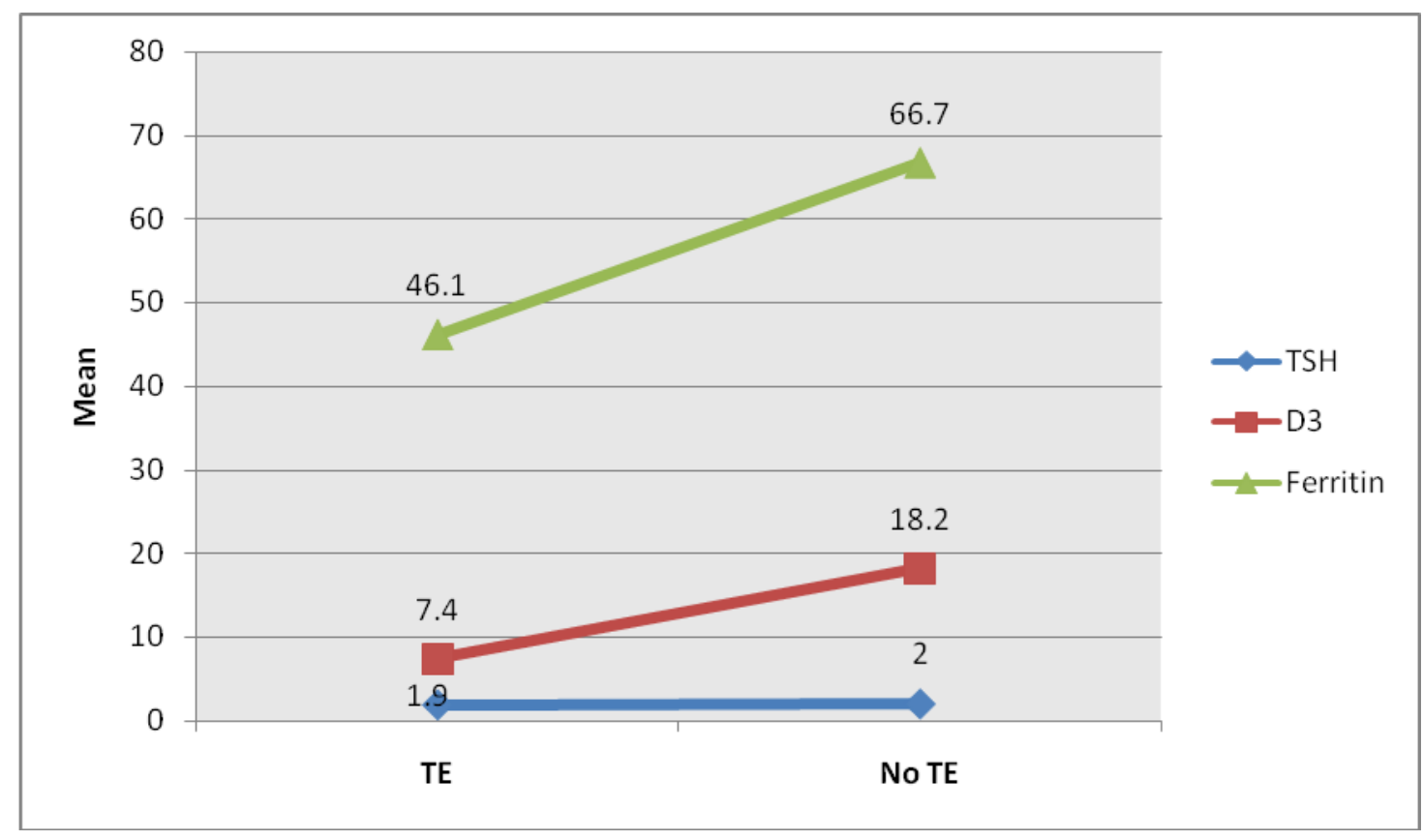

Figure 2: TSH, $\mathrm{D}_{3}$ and Ferritin according to Cases and Controls. 
After controlling family history of hair loss, a significant negative correlation was observed between Vitamin $\mathrm{D}_{3}$ level and TE $(\mathrm{p}<0.001)$. In same way, there was a significant negative correlation between serum Ferritin and TE among studied women $(\mathrm{p}<0.001)$ as shown in table 3.

Table 3: Partial correlation of serum Ferritin and Vitamin $\mathrm{D}_{3}$ levels with TE after controlling family history.

\begin{tabular}{|l|c|c|c|}
\hline Variables & R & DF & P \\
\hline Ferritin (ng/ml) & -3.0 & 197 & $<0.001$ \\
\hline Vitamin $\mathbf{D}_{\mathbf{3}}(\mathbf{p g} / \mathbf{m l})$ & -5.0 & 197 & $<0.001$ \\
\hline $\mathbf{R}=$ Correlation Coefficient, DF=Degree of Freedom. & \\
\hline
\end{tabular}

\section{Discussion}

Hair loss is a prevalent problem among both sexes of all ages. The TE is a common cause of diffuse non-scarring alopecia ${ }^{16}$.TE hair loss is a multifactorial in origin; nutritional, medications, fever, rapid weight loss, etc $^{17}$. Positive family history of hair loss in this study was significantly higher among women with TE than controls. This is similar to results of França et al study which reported that family history may play role in TE hair $\operatorname{loss}^{18}$. The family history is highly prevalent among female having a female pattern hair loss type that was excluded in current study. In present stud, a family history effect was controlled to reveal the significant effect of Ferritin and Vitamin $\mathrm{D}_{3}$ level on TE. Serum Ferritin of studied women with TE in current study was significantly lower than controls which coincide with

many previous literatures 1,19 . Iron deficiency is associated with low serum Ferritin concentrations and low serum Ferritin level is predictor for iron deficiency ${ }^{20}$.The causes of Telogen hair shedding in iron deficiency anemia is not fully understood but might be due to a fact that hair follicle matrix cells as the most rapidly proliferating cells in the body appear to have lower levels of Ferritin and higher levels of free iron ${ }^{21}$. Elledge et al study stated that iron importance for hair originated from its requirement as a cofactor for Ribonucleotide Reductase, the ratelimiting enzyme for DNA synthesis. Therefore, iron deficiency inhibits this 


\section{Email:utjmed@utq.edu.iq}

enzyme, resulting in inhibition of hair proliferation $^{22}$.Another associated problem with anemia is Zinc deficiency and a previous study reported the effect of Zinc deficiency on hair loss ${ }^{17}$. However, effect of iron on TE is still controversial. Sinclair study found no effect of iron as a replacement therapy for $\mathrm{TE}^{9}$.

In present study vitamin $\mathrm{D}_{3}$ level was significantly low among women with TE. This finding is consistent with results of Rasheed et al study ${ }^{2}$ and Amor K, et al study ${ }^{23}$. Vitamin D is necessary to delay aging phenomena, including hair loss ${ }^{22}$; in addition to an important role in the hair follicle cycle, specifically Anagen initiation ${ }^{24}$ and regulation of genes expression required for hair follicle cycling, including the hedgehog signaling pathway ${ }^{25}$. This finding regarding Vitamin $\mathrm{D}_{3}$ is inconsistent with results of Karadağ et al study which found higher Vitamin $\mathrm{D}_{3}$ level among hair loss women with no acceptable explanation ${ }^{5}$.

Thyroid stimulating hormone level of women with TE was not significantly different from TSH level of controls. This finding agreed with results of Moeinvaziri et al study ${ }^{1}$. This was not in agreement with Vincent et al study which reported the importance of TSH for assessment of hair loss among women.

The limitations of present study were its cross sectional design that failed to assess the temporal relationship, concentrating the work in one center so that the study cannot be generalized on Iraqi women and confounding effect of other variables lowering serum Ferritin and Vitamin $D_{3}$ levels that were not excluded in present study. Besides, this study did not investigate other risk factors of TE such as Zinc deficiency, proteins deficiency, etc.

In conclusion, Present study revealed that decreased serum Ferritin and Vitamin $\mathrm{D}_{3}$ among women might play a major role in TE hair loss. There is a demand for universal screening of serum Ferritin and Vitamin $\mathrm{D}_{3}$ not only for women presented with TE but also for women and men presented with other dermatological diseases such as psoriasis, skin cancer, etc., in which Vitamin D and iron might play a role. Further national large sized studies on risk factors of TE are needed.

\section{References}

1. Moeinvaziri M, Mansoori P, Holakooee K, NaraghiSZ, Abbasi A. Iron status in diffuse telogen hair loss among women, ActaDermatovenerol Croat 2009; 17(4):279-284.

2. Rasheed H, Mahgoub D, Hegazy R, El-Komy M, Abdel Hay R, Hamid MA, et al. Serum ferritin and vitamin d in female hair loss: do they play a role? Skin Pharmacol Physiol 2013; 26(2):101-107.

3. Shapiro J. Hair Loss in Women. N Engl J Med 2007; 357:1620-1630.

4. Vujovic A, Del Marmol V. The female pattern hair loss: Review of etiopathogenesis and diagnosis. BioMed Research International 2014 (1): 767628.

5. Karadağ AS, Ertuğrul DT, Tutal E, Akin KO. The role of anemia and vitamin $\mathrm{D}$ levels in acute and chronic telogen effluvium. Turkish Journal of Medical Sciences 2011; 41 (5): 827-833.

6. Bregy A, Trueb RM. No association between serum ferritin levels $>10$ microg/l and hair loss activity in women. Dermatology 2008; 217: 1-6. 


\section{Email:utjmed@utq.edu.iq}

7. Kantor J, Kessler LJ, Brooks DG, Cotsarelis G. Decreased serum ferritin is associated with alopecia in women. $\mathrm{J}$ Invest Dermatol 2003; 121: 985-988.

8. Rushton DH. Decreased serum ferritin and alopecia in women. $\mathrm{J}$ Invest Dermatol 2003; 121: xvii-xviii.

9. Sinclair R. There is no clear association between low serum ferritin and chronic diffuse telogen hair loss. Br J Dermatol 2002; 147: 982-984.

10. Olsen EA, Reed KB, Cacchio PB, Caudill L. Iron deficiency in female pattern hair loss, chronic telogen effluvium and control groups. J Am AcadDermatol 2010; 63: 991-999.

11. Kennedy A, Kohn M, Lammi A, Clarke S. Iron status and haematological changes in adolescent female in patients with anorexia nervosa. J Paediatr Child Health 2004; 40: 430-432.

12. Reichrath J. Vitamin D and the skin: an ancient friend, revisited. ExpDermatol 2007; 16: 618-625.

13. Zlotogorski A, Hochberg Z, Mirmirani P, Metzker A, BenAmitai D, Martinez-Mir A, et al. Clinical and pathologic correlations in genetically distinct forms of atrichia. Arch Dermatol 2003; 139: 1591-1596.

14. Olsen EA. Female pattern hair loss. J Am AcadDermatol 2001; 45:S7080.

15. Charan J, Biswas T. How to calculate sample size for different study designs in medical research. Indian $\mathbf{J}$ Psychol Med 2013; 35 (2):121-126.

16. Springer K, Brown M, Stulberg DL. Common hair loss disorders. Am Fam Physician 2003; 68: 93-108.

17. Harrison S, Sinclair R. Telogen effluvium. Clin Exp Dermatol 2002; 27 : 389-395.

18. França K, Rodrigues T, Ledon J, Savas J, Chacon A. Comprehensive Overview and Treatment Update on Hair
Loss. Journal of Cosmetics, Dermatological Sciences and Applications 2013; 3 (3A): 1-8.

19. Fatani MI, Bin mahfoz AM, Mahdi AH, Alafif KA, Hussain WA Khan AS, et al. Prevalence and factors associated with telogen

effluvium in adult females at Makkah region, Saudi Arabia: A retrospective study. Journal of Dermatology \& Dermatologic Surgery2015; 19: 27-30.

20. Guyatt GH, Oxman AD, Ali M, Willan A, McIlroy W, Patterson C. Laboratory diagnosis of iron-deficiency anemia: an overview. J Gen Intern Med 1992; 7:145-153.

21. Liau G, Chan LM, Feng $P$. Increased ferritin gene expression is both promoted by cAMP and a marker of growth arrest in rabbit vascular smooth muscle cells. J BiolChem 1991; 266:18191826.

22. Elledge SJ, Zhou Z, Allen JB. Ribonucleotide reductase: regulation, regulation, regulation. Trends BiochemSci 1992; 17:119-123.

23. Amor K, Rashid R, Mirmirani P. Does $\mathrm{D}$ matter? The role of vitamin $\mathrm{D}$ in hair disorders and hair follicle cycling. Dermatol Online J 2010; 16:3.

24. Zheng Y, Prouty SM, Harmon A, Sundberg JP, Stenn KS, Parimoo S: Scd3 - a novel gene of the stearoyl-CoA desaturase family with restricted expression in skin. Genomics 2001; 71: 182-191.

25. Demay MB: The hair cycle and vitamin D receptor. Arch Biochem Biophys 2012; 523: 19-21. 


\section{تساقط الثعر : الاسباب المحتملة في العراق}

علاء عبدالحسن نايف

\section{الخلاصة}

الخلقية: يعتبر تساقط الشعر لاى النساء مشكله شائعه وتعتبر تحديا للعديد من اخصائيي

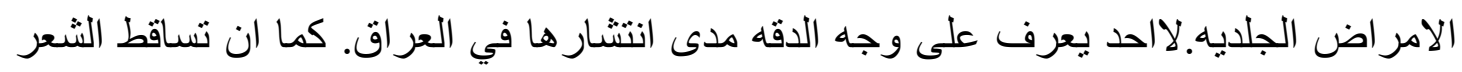

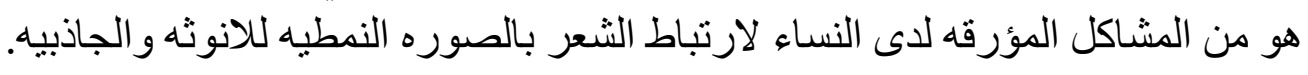

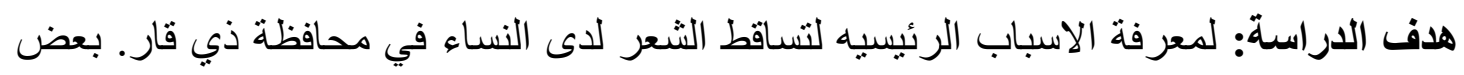

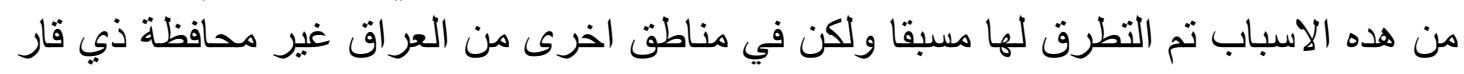

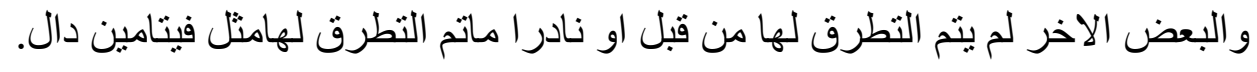

المرضى والطرق: تم اجراء دراسة مسحية على المرضى الوافدين الى استشارية الامراض

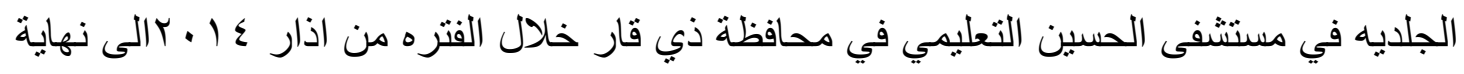

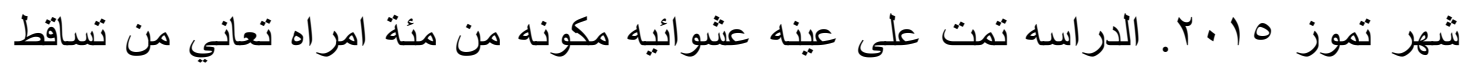

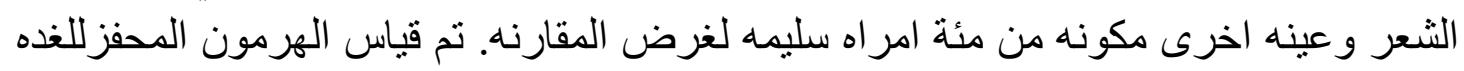
الدرقيه و وخزون الحديد اضافة الى فيتامين دال لدى كلا العينيتين.

النتائج: هنالك ارتباط وثيث بين تساقط الثعرو التاريخ العائلي لتساقط الثعر. ليس هنالك علاقه الثاء تذكر بين مستوى الهرمون المحفزللغده الدرقيه وتساقط الثعر لدى النساء. كما اننا وجدنا لنافي مستويات منخفضه من مخزون الحديد وفيتامين دال في دم النساءالتي تعاني من تساقط الشعر. من الممكن ان يكون لمستوى مخزون الحديد ومستوى فيتامين دال في الدم دور مهم في تساقط

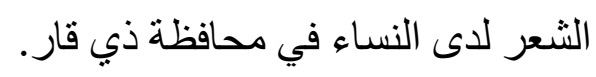

الكلمات المفتاحية: تساقط الثعر ، فيتامين دال، مخزون الحديد، هرمون الغدة الدرقية المحفز. 